Portland State University

PDXScholar

1976

\title{
Effects of Increased Fuel Costs on Households in a Low Income Neighborhood in Portland, Oregon
}

Ora Allen

Portland State University

Betty Heald

Portland State University

Follow this and additional works at: https://pdxscholar.library.pdx.edu/open_access_etds

Part of the Social Work Commons

Let us know how access to this document benefits you.

\section{Recommended Citation}

Allen, Ora and Heald, Betty, "Effects of Increased Fuel Costs on Households in a Low Income Neighborhood in Portland, Oregon" (1976). Dissertations and Theses. Paper 1914.

https://doi.org/10.15760/etd.1913

This Thesis is brought to you for free and open access. It has been accepted for inclusion in Dissertations and Theses by an authorized administrator of PDXScholar. Please contact us if we can make this document more accessible: pdxscholar@pdx.edu. 
EFFECTS OF INCREASED FUEL COSTS ON HOUSEHOLDS

IN A LOW INCOME NEIGHBORHOOD

IN PORTLAND, OREGON

\author{
by \\ ORA ALLEN \\ and \\ BETTY HEALD
}

A research paper submitted in partial fulfillment of the requirements for the degree of

MASTER OF SOCIAL WORK

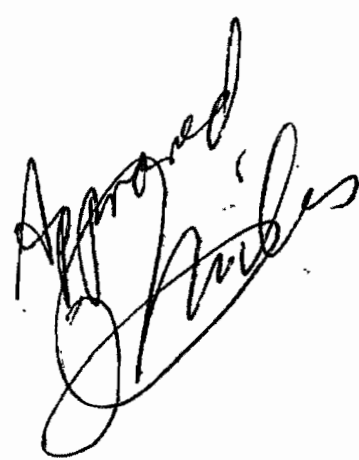

Portland State UnIversity

1976 
TABLE OF CONTENTS

PAGE

LIST OF TABLES AND FIGURES .............. 111

CHAPTER

I INTRODUCTION . . . . . . . . . . . I I

Population ............ . 3

Sampling Method .......... 4

II STUDY OF SAMPLES . . . . . . . . . . . 11

I Characteristics of Interviewed

Sample ............ 11

Household Composition

Sources of Heat

Effects on Household Budget

Adaptations

Relationship of Variables

II Sample Comparing Cost and Thermal

Adjustments ........ 25

III SUMMARY AND CONCLUSIONS . . . . . . 30

APPENDICES

A Advance Letter........... . 33

B Survey Summary Card . . . . . . . 34

C Questionnaire ......... . 35 


\section{LIST OF TABLES AND FIGURES}

TABLE

PAGE

I Income Levels in Albina Population

Area, Portland, Oregon, 1970 ... . 3

II Average First Quarter Temperatures

Selected Years, Downtown Portland . 8

III Age of Members, Interviewed Households • 12

IV Number of Members, Interviewed

Households . . . . . . . . 13

V 1975 Reported Income of Sample Com-

pared w1th 1970 Census . . . . . 14

VI Reported Family Income Levels,

Intervlewed Households . . . . . 15

VII, Home Ownersh1p, Intervlewed Households .. 16

VIII Type of Resldence, Interviewed Households ............ 16

IX Age of House, Interviewed Households . . . 17

$X$ Major Source of Heating Fuel, Inter-

vlewed Households . . . . . . 18

XI Effects on Budgets, Interviewed

Households . . . . . . . . 19

XII Fuel-Saving Adaptations, Interviewed

Households . . . . . . . . . 21 
TABLe F,

$$
\begin{aligned}
& \text { XIII Change in Fuel Use in Therms, } \\
& 1975 \text { Compared with } 1974 \text {. . . . . } 26 \\
& \text { XIV Change In Fuel Cost, } 1975 \text { Compared } \\
& \text { with } 1974 \text {. . . . . . . . } 27
\end{aligned}
$$

FIGURE

$$
\begin{aligned}
& 1 \text { Percentage Changes in Costs and Therms } \\
& \qquad \begin{array}{l}
\text { in } 1975 \text { Compared with 1974, First } \\
\text { Quarter . . . . . . . . . . } 29
\end{array}
\end{aligned}
$$

PAGE

Iv 


\section{CHAPTER I}

\section{INTRODUCTION}

The national energy crisis of the winter of 1974 signaled prospects of severe adjustments in the avallabllity and costs of fuel. Petroleum products became in short supply, and thelr costs rose sharply to consumers. In Portland, Oregon, natural gas as a household fuel was not so Immediately affected, though Northwest Natural Gas Company, Portland's chlef supplier, made modest increases in the ir rates effect1ve January 1, 1974, and again Apri1 1, 1974. A new and more significant increase was authorized by the Oregon Public Ut1lities Commissioner as effective November 24,1974 . Instead of reducing the cost per therm ${ }^{1}$ as the use increased, as on past schedules, the new schedule raised the cost per therm with increased use. These rises in cost In both gas and oll as household fuels also affected the production costs of electricity, and all have begun a spiral that w1ll continue to accelerate sharply as energy sources become more scarce.

${ }^{1}$ One therm is the equivalent of 100,000 British Thermal. Units, a unit of heat equal to 252 calories, or the quantity of heat required to raise one pound of water from $62^{\circ} \mathrm{F}$. to $63^{\circ} \mathrm{F}$. 
This study is made up of two parts which explore some of the effects upon individual households making up a sample of a low income nelghborhood in Portland. The first section In Chapter II presents a survey of sample households in our Identifled area, securing personal information given by adult members along with their responses to questions concerning effects on their budgets and the adaptations they have made to reduce the cost of fuel.

The second section compares costs of fuel for January, February, and March of 1975 w1th the same months of 1974 for another sample in the same area. Amount of fuel was tabulated along with costs, and percentage increases or decreases were charted. The fortunate coincldence of the same three-month average temperature in downtown Portland for both years gave an especially good comparison. The monthly use of gas could be more accurately measured than the use of o1l. None of our interviewed sample were found to use electricity as a primary source of heat.

Since the energy crisis is only recently a widely recognized phenomenon, we found little bibliographic support and relled chiefly on current newspaper articles and bulletins, with interviews with members of our sample households, and selected interviews with other consumers and some suppliers. 


\section{POPULATION}

The area limits of both groups in this study are in an Identifled low income nelghborhood within the perimeter of Portland's Model Clties project generally known as Albina. Using.U.S. Census ${ }^{2}$ figures for 1970, the census tracts with their income statistics were as follows:

TABLE I

INCOME LEVELS IN ALBINA POPULATION AREA, PORTLAND, OREGON, 1970

\begin{tabular}{|c|c|c|c|}
\hline Tract & $\begin{array}{l}\text { Median } \\
\text { Income }\end{array}$ & $\begin{array}{l}\text { Mean } \\
\text { Income }\end{array}$ & $\begin{array}{c}\text { \% of Familles } \\
\text { Below Poverty Level }\end{array}$ \\
\hline $\begin{array}{l}34.01 \\
34.02 \\
33.02 \\
33.01\end{array}$ & $\begin{array}{r}\$ 6,103 \\
6,451 \\
6,259 \\
6,683\end{array}$ & $\begin{array}{r}\$ 7,239 \\
6,849 \\
6,930 \\
8,613\end{array}$ & $\begin{array}{l}25.5 \\
30.8 \\
22.3 \\
17.8\end{array}$ \\
\hline \multicolumn{4}{|c|}{ Portions of: } \\
\hline $\begin{array}{l}35.01 \\
35.02\end{array}$ & $\begin{array}{l}2,976 \\
7,125\end{array}$ & $\begin{array}{l}4,191 \\
7,352\end{array}$ & $\begin{array}{l}44.8 \\
40.2\end{array}$ \\
\hline
\end{tabular}

Boundaries of the area are Fremont Street ( 3500 block) on the south, K1llingsworth Street ( 5500 block) on the north, the Minnesota Freeway on the west, and Northeast 15th Avenue on the east.

2 Bureau of the U.S. Census, Census Tracts: Portland, ore.-Wash. Standard Metropolitan Statistical Area: 1970. 


\section{SAMPLING METHOD}

We had hoped to draw our interviewing sample from gas users in the billing sample provided by Northwest Natural Gas Company. After considerable discussion with representatives of the Company, we found them wishing to be cooperative, but concerned about their position in respect to the confidentiality of their customers' records. The Company officlals finally agreed to draw us a listing of billings for the two quarters requested from meter runs within the area to be surveyed. They were willing to do their own hand-comparison of those who had resided at the same address during the two quarters requested, and to furnish us with print-outs of the billings showing therms used and bill amounts by month. All identifying names and addresses were removed to guard the privacy of their users. We were assured that the 142 customer records met all of our criteria for area and time of residence.

$$
\text { Since we were not able to draw our interview sample }
$$

from this Gas Company listing, we drew an independent sample for our interviews from the same geographical area. We used Polk's 1974 Portland C1ty Directory, complled in 1973, which would be most likely to give us names of residents at the addresses of our random sample for the time covered by our survey. Determining that the census tracts being 
covered gave the total of housing units in the area as 5.333, we set a goal for a sample of near 100. We came up with elghty-five addresses. In the process we eliminated hotels, businesses, lodges, clubs, schools, dormitories, social agencies, and apartments that did not have individual addresses. We wanted residents who paid their own heating bills rather than having cost of fuel included in rent charges.

Our final 11st resembled the billing list from the Gas Company in area of residence, and both samples were blased In having more stable householders, 1.e., those who had Ilved at the same address and had been responsible for their own fuel bills for both the first quarter of 1974 and that of 1975 .

Upon approaching the elghty-five households for intervlews, we eliminated forty-one of them for these reasons:

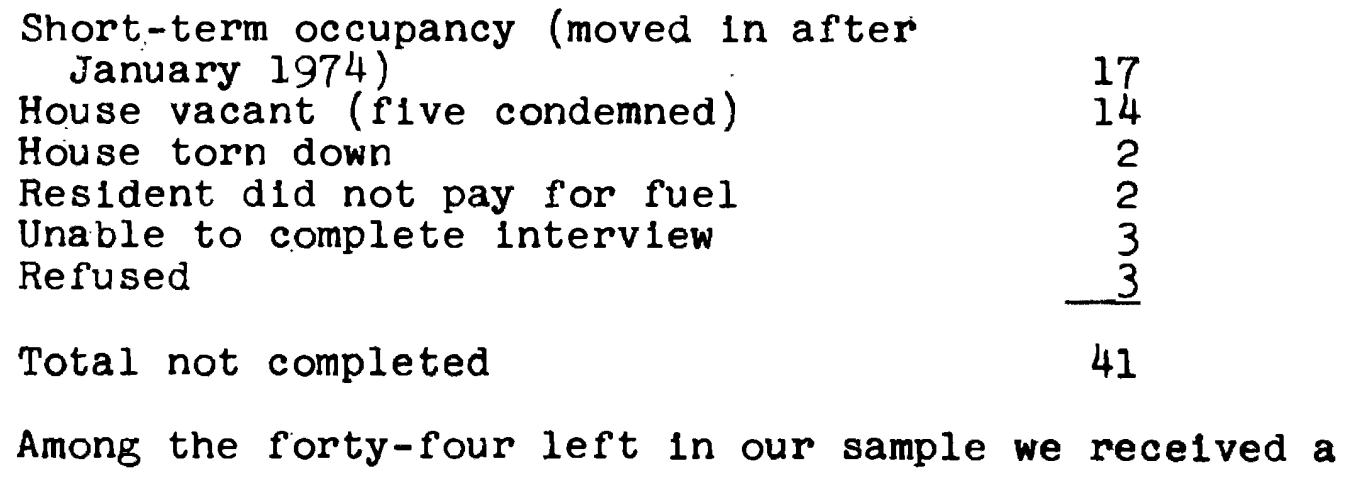

Total not completed

41

Among the forty-four left in our sample we recelved a high level of cooperation and interest. Generally the respondents were positive, thoughtful, and apparently open in 
their answers. We had most reason to question their responses as to income, but knowledge of standard welfare and Social Security payments gave us a double check. All answers appeared plausible within the monthly and yearly ranges we used with the exception of two which were omitted from measurements in which income was a variable. In these instances there was a total number of forty-two cases rather than forty-four.

Interviewing of the forty-four households was done in August 1975 with the final call-backs completed during the first week in September. Working as a palr, one did all interviewing while the other did all recording in order to elicit as uniform responses as possible. A standard form and order of questions (Appendix $C$ ) and a summary card with brief forms for recording (Append1x B) were used. The general hypothesis which we wished to test was that both samples would indicate significant strains in meeting the costs of fuel in 1975 over 1974. In our survey we approached this attitudinally; in our use and cost comparison we sought measurable support. We also wished to test further that the higher the income, the more adaptations would be in the nature of more costly home improvement; conversely, the lower the income, the more the adaptations would be informal, personal, and low in cost. We also tested that those owning or buying homes would make more 
costly adaptations in the nature of home improvement, that more black families than white families would recelve incomes below the median, and that families with children would have more difficulty with budget and prompt payment. W1th the November 1974 increase in the cost of gas, it was predicted by the supplier that this would signal a 12 per cent to 17 per cent increase. We wished to compare the use in the 142-household sample for the two quarters, expecting to find that, in view of the difficulties in heating old, high-cellinged homes, those who might least be able to afford the increases would be in the upper levels of percentage increases.

A Salvation Army official who assisted in distributing emergency fuel in February 1.974 to those in substandard housing who were completely without fuel sald,

Remember that we're talking about the homes of the poor, those homes with high cellings, without proper insulation, with no storm windows and no weather stripping and heavy drafts . . (winter requests for fuel in those houses) wouldn't be extraordinary at 300 gallons a month.

During this perlod of petroleum shortage the local Fuel Clearing Bureau, an emergency coalition administered by the Salvation Army, gave out emergency amounts of $\$ 40.00$ per family, or 100 gallons of fuel oll. From the same source as above, 
We're using Food Stamp guidelines as our Income standard. A single person can't have an income of more than $\$ 194$ a month and st1ll get help, for instance. So, if they have to pay rent and eat and then face a big bill for fuel, you know what has to give - the fuel. They go without.

Both winters of 1974 and 1975 were moderate as measured by U.S. Weather Bureau standards. 3 Averages for the three-month period in downtown Portland were the same for both winters and just $1.3^{\circ}$ below the Bureau's average for a previous thirty-year period.

TABLE II

AVERAGE FIRST QUARTER TEMP FRATURES SELECTED YEARS, DOWNTOWN PORTLAND

\begin{tabular}{lcccc}
\hline \hline & January & February & March & $\begin{array}{c}\text { Three-Month } \\
\text { Average }\end{array}$ \\
\hline 1974 & $37.9^{\circ}$ & $43.0^{\circ}$ & $47.1^{\circ}$ & $42.6^{\circ}$ \\
1975 & $41.5^{\circ}$ & $41.2^{\circ}$ & $45.0^{\circ}$ & $42.6^{\circ}$ \\
$1921-50$ & $39.5^{\circ}$ & $43.8^{\circ}$ & $48.4^{\circ}$ & $43.9^{\circ}$ \\
\hline
\end{tabular}

In addition to our personal interviews with householders, we informally interviewed two fuel suppliers who sell to customers in our area.

Company "A" is a Black-owned business with a large percentage of low to middle income customers. This company has operated in the area since the early $1940^{\prime} \mathrm{s}$ and has

3U.S. Weather Bureau, ClImatography of the Un1ted States, Oregon, No. 60-35. 
built up a business by credit billing, accepting personal checks, and otherwlse extending extra services to delinquent customers who may have extenuating circumstances but find it difflcult to pay on time. The company representative stated that over the two winters of our sample period his customers have seen a 6.5 per cent increase in the cost of o11, and although there was an attempt on the company's part to keep increases at a minimum, it was necessary to share 1 t with the customers. He thought continued increases could be assumed.

Most of Company "A' $s$ " flxed-1ncome customers use the ir service on call and order 100 gallons of oll at a time. Their delivery hours are from 7:00 a.m. to 6:00 p.m., with a half day on Saturdays. The representative stated that although drivers do not work on Sundays or holldays, they have been known to make late deliverles for the eonvenience of regular customers who may have emergencles.

Company " $B$ " is a city-wide company with a branch in the area. The representative reported that most of their customers utilize their automatic-fill service. The customer is billed monthly and payments are on a revolving account system. Their nonregular and new, nonestablished customers must pay on del1very. Drivers w1ll not accept personal checks without prior approval of the manager. The 
company had no direct figures avallable, but we were told that their prices were competitive and in line with those of other companies.

Our summary w1ll bring together both attitudinal and statistical data and project implications for soclal planners and direct service workers. 
CHAPTER II

STUDY OF SAMPLES

\section{CHARACTERISTICS OF INTERVIEWED SAMPLE}

Our Initial assumption was that households having chlldren, young people, or elderly might be less able to make fuel-saving adaptations than other households of those with fewer or less speclalized needs. We were interested also in the signiflcance of income; ownership; and race. Finally, we wanted the householders' responses on budget strain and personal adaptation.

Household Composition

Age of Members. Our first question grouped household members Into preschool, school age, adults in the wide range from legal majority to approximate retirement age, and those whose living hablts $m$ lght have changed owing to retirement. Th1s might have been measured more prec1sely by considering employment, state of health, or other indicators of activity inside or outside the home. Age still appeared to give one measure. 
TABLE III

AGE OF MEMBERS, INTERVIFWED HOUSEHOLDS

\begin{tabular}{lll}
\hline $0-5$ years & 5 & $11.36 \%$ \\
$6-18$ years & 15 & $34.09 \%$ \\
$19-64$ years & 29 & $65.91 \%$ \\
$65+$ & 20 & $45.45 \%$ \\
\hline
\end{tabular}

The largest group were adults in the group covering the widest range of years, as might be expected. There were comparatively few households with children. Nearly half of the total number of persons were age sixty-five and older. Among the total number were a noticeable number suffering disabilities. Several of those we interviewed admitted to being over eighty though only two over sixty-five were 111 . It was our observation that these were already making max 1mum adjustments for saving on fuel.

Number of Household Members. We expected that the size of the household might relate to the income, whether influencing subsidy income or multiple sources. 
TABLE IV

NUMBER OF MEMBERS, INTERVIEWED HOUSEHOLDS

\begin{tabular}{lrr}
\hline \hline & 13 & $29.55 \%$ \\
One person & 10 & $22.73 \%$ \\
Two persons & 7 & $15.91 \%$ \\
Three persons & 5 & $11.36 \%$ \\
Four persons & 6 & $13.64 \%$ \\
F1ve persons & 1 & $2.27 \%$ \\
Six persons & 2 & $4.55 \%$ \\
Seven persons & $\underline{2}$ & $100.01 \%$ \\
Totals & 4 & \\
\hline
\end{tabular}

The largest percentage, 30 per cent, of households were made up of single persons. The largest number in living groups were in two homes with seven persons each. Five homes had preschool children, fifteen had chlldren from six to elghteen years, and twenty had adults sixty-five years and older.

Household Income. Reported household income from all sources ranged from three households under $\$ 1,500$ to one fam$11 y$ in the $\$ 19,500-\$ 20,999$ group (one of our households with seven members). We used steps of $\$ 1,500$ and found the mean income to be $\$ 6,214$ and the median within the group from $\$ 4,500-\$ 5,999$, setting it at $\$ 4,812.50$. These can be compared to the 1970 Bureau of Census figures for the census tracts involved: 
TABLE V

1975 REPORTED INCOME OF SAMPLE COMPARED WITH

1970 CENSUS

\begin{tabular}{|c|c|}
\hline $\begin{array}{l}\text { Average median income for Census } \\
\text { Tracts } 33.01,33.02,34.01 \text {, } \\
34.02,35.01,35.02,1970\end{array}$ & $\$ 5,932.00$ \\
\hline $\begin{array}{l}\text { Reported median income of } \\
\text { sample, } 1975\end{array}$ & $4,812.50$ \\
\hline $\begin{array}{l}\text { Average mean income for above } \\
\text { Census Tracts, } 1970\end{array}$ & $6,862.00$ \\
\hline Mean income of sample & $6,214.00$ \\
\hline
\end{tabular}

While in our survey we depended on the interviewees' self-report of their estimated income, most seemed definite In knowing how much they recelved per month, especlally those in the lower ranges. These comparisons would indicate that those of our sample rank well below the 1970 median and mean incomes when the percentage of famllies below poverty level ranged from 17.8 per cent to 44.8 per cent in those areas. U.S. Bureau of Census ${ }^{4}$ gives the poverty level of a nonfarm fam1ly of four as $\$ 5,038$ in 1974 .

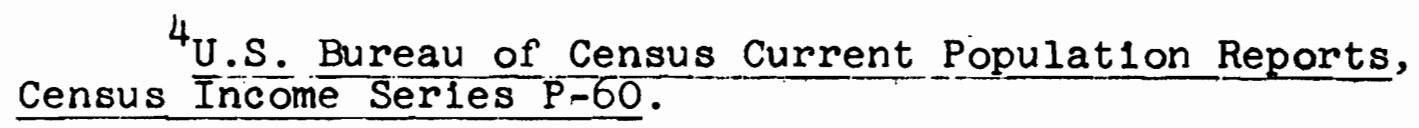


Since we did not ask questions about employment, we had no way of knowing if this was a factor in the relatively lower median and mean incomes.

TABLE VI

REPORTED FAMILY INCOME LEVELS, INTERVIEWED HOUSEHOLDS

\begin{tabular}{lrr}
\hline & 3 & \\
$\$ 0-\$ 1,499$ & 2 & $4.14 \%$ \\
$\$ 1,500-\$ 2,999$ & 11 & $4.76 \%$ \\
$\$ 3000-\$ 4,499$ & 8 & $26.19 \%$ \\
$\$ 4,500-\$ 5,999$ & 9 & $19.04 \%$ \\
$\$ 6,000-\$ 7,499$ & 2 & $21.42 \%$ \\
$\$ 7,500-\$ 8,999$ & 2 & $4.76 \%$ \\
$\$ 9,000-\$ 10,499$ & 2 & $4.76 \%$ \\
$\$ 10,500-\$ 11,999$ & 0 & $4.76 \%$ \\
$\$ 12,000-\$ 13,499$ & 1 & $0 \%$ \\
$\$ 13,500-\$ 14,999$ & 0 & $2.38 \%$ \\
$\$ 15,000-\$ 16,499$ & 1 & $0 \%$ \\
$\$ 16,500-\$ 17,999$ & 0 & $2.38 \%$ \\
$\$ 18,000-\$ 19,499$ & 1 & $0 \%$ \\
$\$ 19,500-\$ 20,999$ & 42 & $2.38 \%$ \\
Totals & & $99.97 \%$ \\
Median income: $\$ 4,812.50$ & & \\
Mean income: $\$ 6,214.00$ & & \\
\hline
\end{tabular}

According to our survey; the median income was $\$ 1,119.50$ below the 1970 level, and the mean Income was $\$ 648$ less.

Home Ownership. Only 25 per cent of our sample were renting their homes; the remainder were in the process of buying, and over a third of them had homes already paid for. 
Since our sample excluded apartments with a group address, we arrived at a sample made up of more than 90 per cent single-family dwellings.

TABLE VII

HOME OWNERSHIP, INTERVIEWED

HOUSEHOLDS

\begin{tabular}{lll}
\hline Renting & 11 & $25.00 \%$ \\
Buying & 16 & $36.36 \%$ \\
Own (paid for) & 17 & $38.66 \%$ \\
Totals & 44 & $100.02 \%$ \\
\hline
\end{tabular}

TABLE VIII

TYPE OF RESIDENCE, INTERVIEWED

HOUSEHOLDS

\begin{tabular}{lrr}
\hline \hline Single family & 41 & $93.18 \%$ \\
$\begin{array}{l}\text { Duplex } \\
\text { Apartment }\end{array}$ & 3 & $6.82 \%$ \\
Totals & -0 & $0 \%$ \\
& 4.4 & $100.00 \%$ \\
\hline
\end{tabular}


TABLE IX

AGE OF HOUSE, INTERVIEWED

HOUSEHOLDS

\begin{tabular}{lrr}
\hline & & \\
$0-9$ years & 0 & $0 \%$ \\
$10-19$ years & 0 & $0 \%$ \\
$20-29$ years & 1 & $2.27 \%$ \\
$30-39$ years & 2 & $4.55 \%$ \\
$40-49$ years & 3 & $6.82 \%$ \\
$50+$ years & 38 & $86.36 \%$ \\
Totals & 44 & $100.00 \%$ \\
\hline
\end{tabular}

It was apparent by the style and condition of the houses that we were working in one of Portland's older neighborhoods. We came upon such historical evidence as hitching rings in the curbing and old street designations. Over 85 per cent of the owners reported their homes to be over fifty years old, and none of them were known to be below the twenty to twenty-nine year level. Many of the homes had undergone extensive remodeling, some during the period of Model Cities low-cost loans. Many showed enterprise in repairs and painting that made them more livable and attractive. Most of the more recently-bullt housing in the area was multi-unit apartments.

Sources of Heat

We wished to determine the principal source of heat for this sample of households to determine how close the 
relationship of this sample might be to our all-gas sample in the study of comparative costs for the two winters of 1974 and 1975.

TABLE $X$

MAJOR SOURCE OF HEATING FUEL, INTERVIEWED HOUSEHOLDS

\begin{tabular}{lrr}
\hline & 0 & $0 \%$ \\
Electricity & 12 & $27.27 \%$ \\
Natural gas & 32 & $72.73 \%$ \\
O1l & 44 & $100.00 \%$ \\
Totals & \\
\hline
\end{tabular}

A little over a quarter of our sample households used natural gas as their primary heat source. The remainder used oil. None used electricity as a chief heating source, though some used electric heaters or their electric ovens as a supplementary or even sole emergency source. Th1s use would add to the escalating cost of fuel, as electriclty had also begun a serles of sharp rises in cost.

Effects on Household Budget

Less than a quarter of the families interviewed sald that they had noticed no appreciable effects on their budgets from the increased cost of fuel by our measures. The remainder reported some degree of difficulty, and elght sald that they had been without heat at some time during the past 
winter of 1975 . One woman with children reported that she was still paying off in August her last winter's gas bill so that she could have it turned on again in the fall. Since we found that Northwest Natural Gas gave personal service by way of extending payments and delaying turn-off for some time, we were aware of just how severe this woman's difficulty might be.

To the question, "How has the increased cost of fuel affected your household budget?" we scaled the responses with the following answers:

TABLE XI

EFFECTS ON BUDGETS, INTERVIEWED HOUSEHOLDS

\begin{tabular}{lcc} 
None & 10 & $22.73 \%$ \\
$\begin{array}{c}\text { Strain, but no sacri- } \\
\text { fice of essentials }\end{array}$ & 8 & $18.18 \%$ \\
$\begin{array}{c}\text { Juggle bills, pay } \\
\text { late }\end{array}$ & 18 & $40.90 \%$ \\
$\begin{array}{l}\text { Without heat at } \\
\text { some time }\end{array}$ & 8 & $18.18 \%$ \\
Totals & 44 & $99.99 \%$ \\
\hline
\end{tabular}

Other responses Included "I use food money," and "When the heat was turned off, the kids also had bad colds." 
Adaptations

To our question, "What have you done to cut down or save fuel?" no one answered "nothing." We classifled responses by personal, informal, or comparatively inexpensive measures on the one hand and household improvements that required considerable expense on the other. Those measures that we considered in the first category, that 1s, the more personal measures or less costly adaptations, we deslgnated minor, marked minus (-); the more costly home improvements we designated major, marked plus $(+)$ in Table XII.

We had planned to lump floor insulation with carpetIng as a costly adaptation. We found that none of our respondents used floor insulation (one mentioned closing of $f$ the foundation space), while some of the long-time residents had had carpeting for many years. Some of the added carpets, as recent warming measures, were used or makeshift and could not be considered a costly adaptation in response to a need for saving fuel, thus we scored this measure as a personal one, or minus in our designation.

The use of auxillary electric heat we considered an unplanned or expedient adaptation and scored it as personal, although it could add considerable cost. 
TABLE XII

FUEL-SAVING ADAPTATIONS, INTERVIEWED HOUSEHOLDS

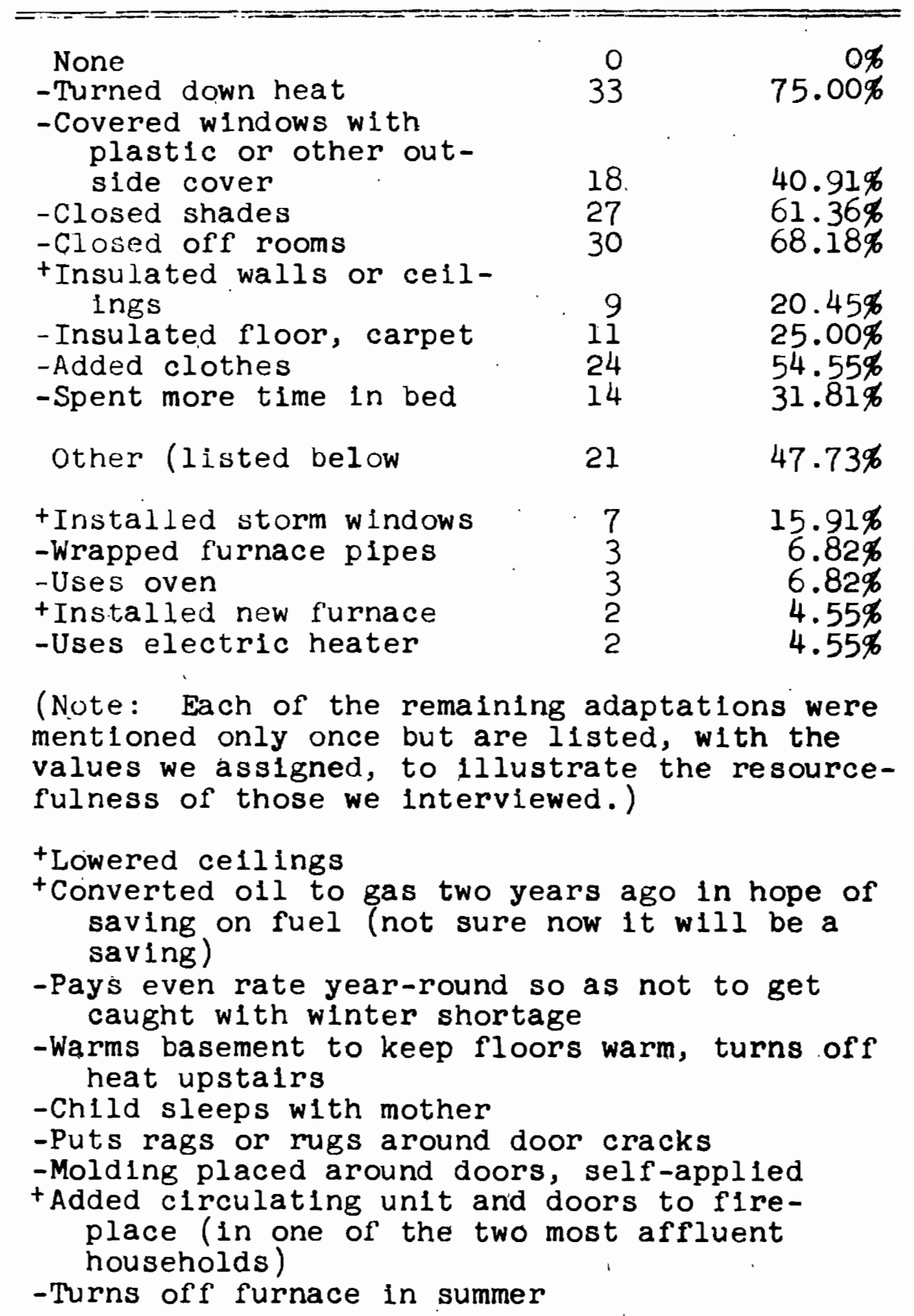


TABLE XII-- Continued

-Uses less hot water

-Spends more time in kitchen (warmer where cooking is being done)

-Closes off fireplace

-Drinks coffee to warm up

-Stays in bed with electric blanket when chllied (elderly lady)

-Puts masking tape over cracks around windows

+Installed storm doors

-Uses old wood circulating heater in basement; heats with avallable waste wood, keeps upstalrs floor warm and saves on furnace fuel

-Closes off foundation space in winter

Added personal information included offers of tips on budget-stretching that we could pass on to others. Several asked if they could help us further and wished to be informed of the results of the survey. Some told us that they received assistance on costly adaptations or major purchases from friends and relatives. There was evidence of informal networks of family, friends, clubs, or churches that helped some of these people to adapt as well as they have. We were impressed by some of those in our over-sixtyfive group. Most live alone, and only two were physically 111. One gentleman was suffering from the recent death of his wife and was in the process of preparing himself, f'inancially and emotionally, for selling his home. Another 
was managing to stay in his home with the help of friends after an injury sustained on the job he still held after retirement age.

One of the most resourceful of the elderly was a lady, elghty-three years old, of Finnish descent, living alone on a meager Social Security income. She had recently lost her husband, but was keepling a vegetable and flower garden and had recently palnted "all of her house and garage that she could reach." She proudly showed us through her well-kept home, where she sewed on an anclent treadle sewing machine. She showed us the appliances her niece and nephew had given her, took us through her Immaculate basement to show us her wrapped furnace plpes, and gave us cholce roses when we left. She does not use food stamps and feels that the inconvenience of obtalning them would outwelgh the advantages. Th1s lady was an 1mmigrant; people of her age have survived two world wars and a major depression, and they have done so with some style when they have their health, their home, and sufficlent income. With her present minimal income we can foresee nothing but a sacrifice of essential needs. She could be helped to obtain food stamps, but those in her income bracket will need help with fuel also at the present rate of increasing costs. 
Relationship of Varlables

Our expectations with reference to factors influencing the kinds and degrees of adaptations were put in the form of hypotheses and tested by chi-squares at the .05 level of significance. The null hypothesis was accepted in all cases. Not one of the hypothetical relationships was found to be tenable.

The hypotheses and certain varlables on which they were tested are as follows:

1. The lower the income, the more personal the means of adaptation.

Factors that may have influenced this result could be seen in the high rate of ownership: old homes were pald for, taxes in the nelghborhood are low, and living costs could be put into improvements. Several of the major Improvements to homes had been done under Model Cities lowcost loans, and some had been accomplished just before recent retirements while the household income was higher. These improvements were made in anticlpation of the need to keep costs down and Increase comfort with the onset of lowered retirement income.

2. The lower the income, the slower the payment.

3. Homeowners make more costly adaptations.

4. More black families than white families are below the median income. 
5. Households with preschool children ( $0-5$

years) are slower in making payment.

6. Households with family members under 18 years are slower. in making payment.

7. Black families are slower in making payment for fuel than white families.

Since the null hypothesis was accepted in all cases, conclusions were that income, ownership, race, and age are not critical factors in the kinds of adaptation and the difflculty in paying higher fuel bills in this population. The responses show widespread efforts to save fuel and adapt to rising fuel costs. With 18 per cent of the households reporting some strain in meeting fuel costs, 41 per cent already juggling bills and paying late, and 18 per cent reporting that they were without heat part of the time, one can speculate that new increases will have increasingly severe effects.

\section{SAMPLE COMPARING COST AND THERMAL ADJUSTMENTS}

We were provided with billing data from monthly statements giving number of therms of fuel used and costs for 142 fas users in the same geographical area as that of our survey sample in Section I. Northwest Natural Gas Company supplied print-outs to cover as nearly as possible the months of January, February, and March for both 1974 and 1975 at each address. These were like our survey sample in 
that they had lived at the same address for both quarters. The three months' costs and therms were averaged for each year for each of the 142 cases.

Using the 1974 averages as 100 per cent, the percentages of Increase and decrease were computed for both therms and cost, ranging as below:

TABLE XIII

CHANGE IN FUEL USE IN THERMS,

1975 COMPARED WITH 1974

\begin{tabular}{cccc}
\hline $\begin{array}{c}\phi \\
\text { Increase }\end{array}$ & $\begin{array}{l}\text { Number } \\
\text { Of Users }\end{array}$ & Decrease & $\begin{array}{c}\text { Number } \\
\text { Of Users }\end{array}$ \\
\hline $0-4$ & 12 & $0-4$ & 24 \\
$5-9$ & 7 & $5-9$ & 26 \\
$10-14$ & 6 & $10-14$ & 29 \\
$15-19$ & 2 & $15-19$ & 13 \\
$20-24$ & 1 & $20-24$ & 17 \\
$25-29$ & 2 & $25-29$ & 8 \\
$30-34$ & 1 & $30-34$ & 2 \\
& - & $35-39$ & 2 \\
Totals & 31 & & 111 \\
& & & \\
& & &
\end{tabular}


TABLE XIV

CHANGE IN FUEL COST, 1975

COMPARED WITH 1974

\begin{tabular}{cccc}
\hline$\%$ & $\begin{array}{c}\text { Number } \\
\text { of Users }\end{array}$ & $\begin{array}{c}\% \\
\text { Decrease }\end{array}$ & $\begin{array}{c}\text { Number } \\
\text { Of Users }\end{array}$ \\
\hline $0-4$ & 9 & $0-4$ & 8 \\
$5-9$ & 17 & $5-9$ & 6 \\
$10-14$ & 22 & $10-14$ & 1 \\
$15-19$ & 28 & $15-19$ & 1 \\
$20-24$ & 21 & $20-24$ & \\
$25-29$ & 11 & & \\
$30-34$ & 8 & & \\
$35-39$ & 2 & & \\
$40-44$ & 2 & & \\
$45-49$ & 1 & & \\
$50-54$ & 2 & & \\
$55-59$ & 1 & & \\
Totals & 124 & & \\
\hline
\end{tabular}

Since the average temperature for the three-month perlod for the two years, 1974 and 1975, was nearly 1dent1cal, or $42.6^{\circ}$ in downtown Portland, the comparison indicates that gas users in this population made substantial efforts to reduce the $1 \mathrm{r}$ use of fuel, an average of a 7 per cent decrease for the 111 of the sample who used less in 1975 than in 1974. At the same t1me, 124 of the sample pald an average of 16 per cent more for fuel, supporting our general hypothesis that those in a low income nelghborhood would have more difficulty in adjusting to the higher cost of fuel. 
Estimates for gas users in the 1974 increase period was a 12 per cent - 17 per cent rise in cost.

The scatter diagram, Figure 1, page 29, portrays the distribution of percentage increases and decreases graphically. The $X$ axis represents the 1974 fuel use in therms; the $Y$ axis shows the 1974 costs. The distribution of cases Indicates that 22 per cent increased both therms and costs, 13 per cent decreased both therms and costs, and 65 per cent were concentrated in the area of decreased therms and increased costs.

A careful study of Figure 1 might ralse a question in such an instance as the two cases in which therms were decreased 20 - 25 per cent and costs increased, and in the five cases with similar therm decrease in which costs decreased. Blils were actually nearly identical for the two years in these cases. Since we did not place any cases on the zero line, a few cents difference accounted for placing them above and below the line.

A sample of the actual billing differences was made, averaging thirty of the 142 cases. Therm and cost variations ranged from a three-month increase of 105.8 therms with a corresponding increase of $\$ 40.09$ in cost, to a decrease of 429.2 therms with still an increase of $\$ 7.11$ in cost. Average therm decrease of this sample was 12 per cent wh1le costs increased an average of 12 per cent. 


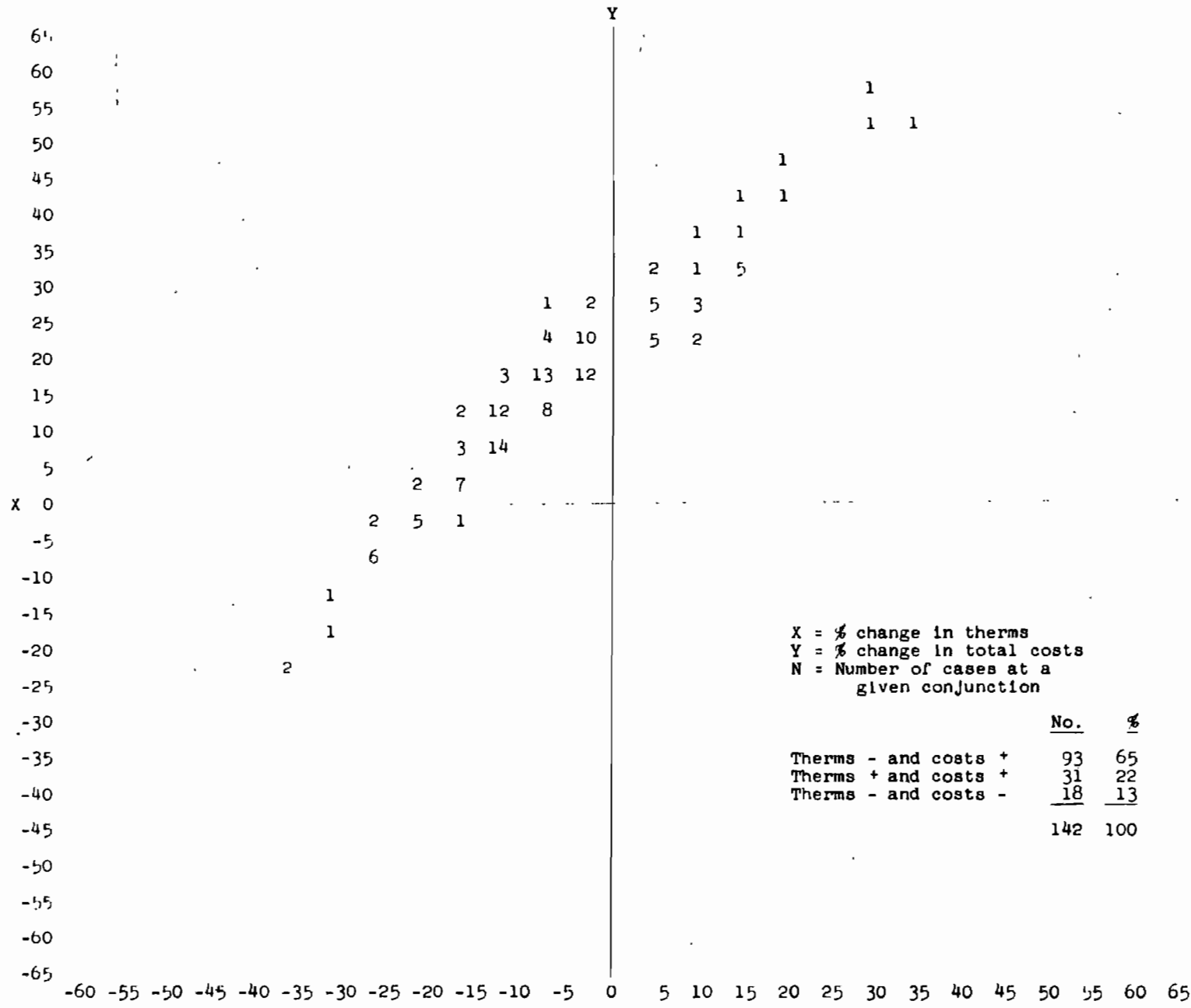

Figure 1. Percentage changes in costs and therms in 1975 compared with 1974, f1rst quarters. 


\section{CHAPTER III}

\section{SUMMARY AND CONCLUSIONS}

Without exception the people in this study had taken measures to reduce their fuel consumption for heating purposes. Some of the measures were positive, but many were at the expense of comfort. A wide varlety of adaptive measures are known to the people. Their employment depends upon a number of interrelated factors.

Little is to be gained by public exhortation to cut down on fuel or by campalgns to instruct these people how to do so. A slzable proportion of the sample had already taken measures beyond that which has been traditionally acceptable. Three-fourths were living at a lower level of comfort. Much more than half were sacrificing essentlals, juggling bills, paying late or actually going without any heat some of the time.

The survey was taken after relatively mild winters and near the beginning of rises in fuel prices. We can only project a more dismal picture for average or more severe winters, multiplied by the anticipated rises in the cost of fuel and other costs. 
For homebound persons especlally--the retlred, the slck, Invalids, elderly, and young children--the plcture portends not only discomfort and sacriflce, but misery.

It is not the function of this report to suggest elther remedies or preventive measures. Some partial efforts at alleviation have been instituted and others discussed, but few in our sample had been reached and fewer still, effectively.

Judging from our samples, reliance on additional money payments for fuel alone would not be sufficlent, and would be complex to administer because of varying sources of income. Reductions in fuel charges for low income persons would help, but would be insufficlent. Programs for repalr and insulation, especially for the chronically 111 and aged homeowners, would help that class. This is already being tried on a small scale, but does not reach many of those represented by our samples. Such a program must be much more direct, Immediate and extensive than any now contemplated. Because of the relationship of fuel to other expenditures, considerable emergency service is needed on top of all other measures.

W1despread publicity and a case-finding program are called for in our population, which tends to be self-reliant on the one hand but with limited income and knowledge or acceptance of helpling programs. 
Accustomed as we are in this climate to year-round provisions for body comfort, we must not lose sight of the deprivation, curtailment of activities, and actual misery a considerable number of people will undergo unless strong action is taken.

Social work has generally considered itself largely successful in alleviating the extremes of physical discomfort. We must reconsider, not only locally, but nationally. 


\section{APPENDIX A}

ADVANCE LETTER

1122 NE Killingsworth

Portland, Oregon

Dear Sir or Madam:

We are conducting a university research project to study the effects of the increased cost of fuel to individual users in your nelghborhood. We will be interviewing in your area within the next month and would like to ask your help in our study. We hope you will consent to being interviewed when we stop at your home.

The results of our questionnalre will be tabulated without using your name, address, or any other identification. We hope the results of our study will be useful in focusing on the effects and adjustments of householders to greater fuel costs.

If you are busy when we stop by, we hope we can arrange a more convenient time.

Sincerely yours,

(Mrs.) Ora Allen

(Mrs.) Betty Heald 


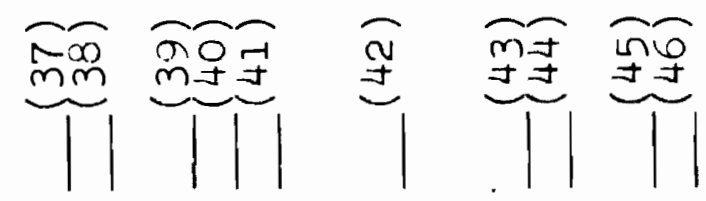

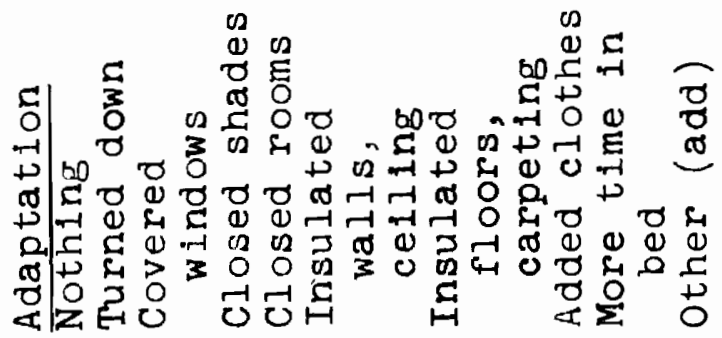

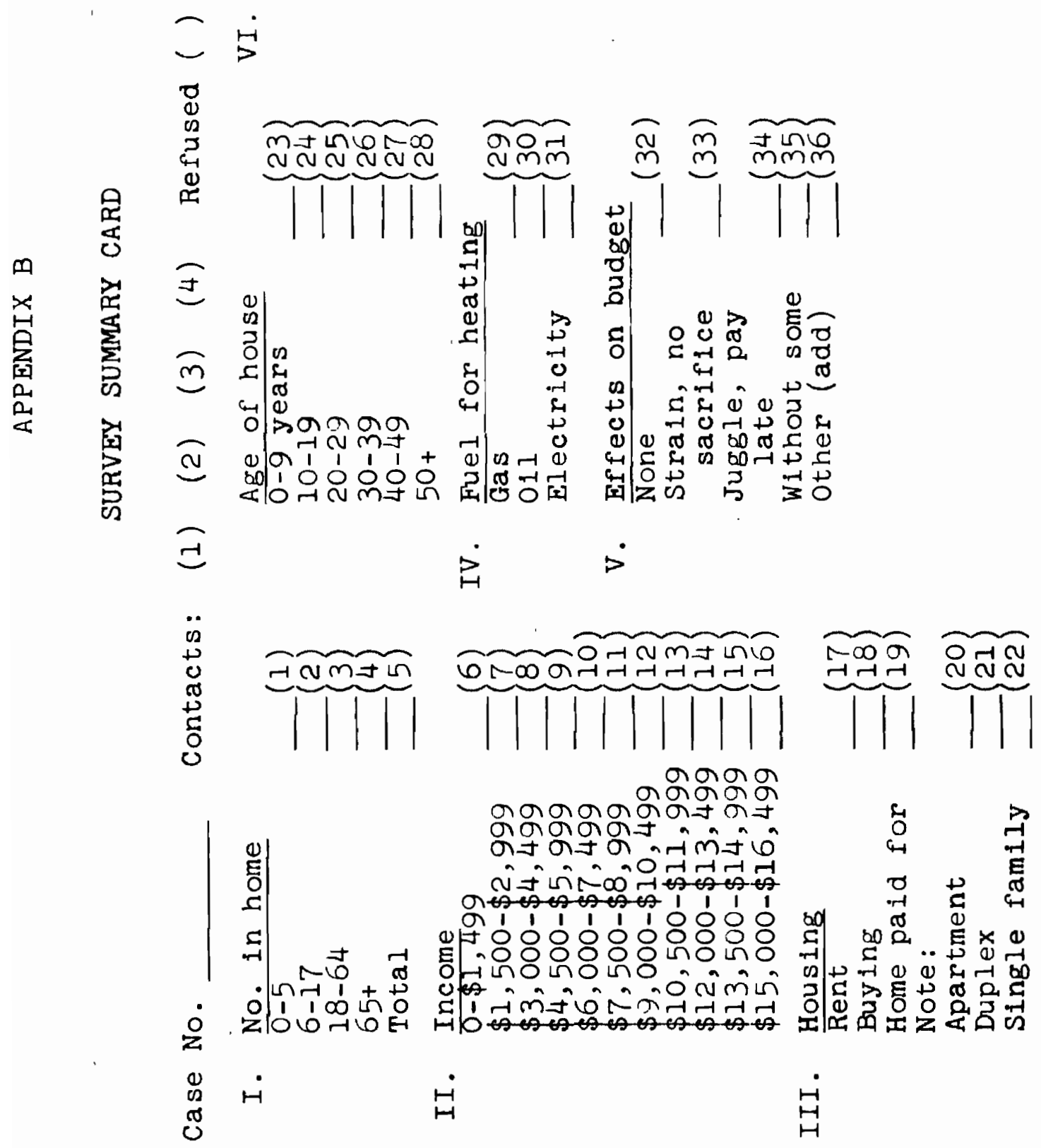




\section{APPENDIX C}

\section{QUESTIONNAIRE}

(Suistance of introduction to survey on effects of increased fuel costs on sample population, Albina)

I am Mrs. Allen and this is Mrs. Heald. We are graduate students from Portland State University, and we are working on a survey regarding the effects of the last year's increased cost of fuel in this area. Your home was selected by random sample. Did you recelve the letter we malled you a f'ew days ago?

We would like to assure you that if we interview you, nelther your name nor address will be used. May we talk with you?

(Questions)

I. Household composition:

How many people live in your home?

$\begin{array}{ll}\text { Preschool } & 0-5 \\ \text { School age } & 6-17 \\ \text { Adult } & 18-64 \\ \text { Senior } & 65+ \\ \text { Total } & \end{array}$

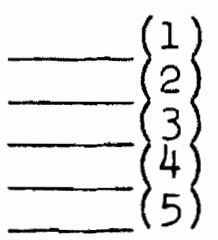

(Be sure interviewee is included.) 
II. Income

In what range is your total yearly income? Include incomes of all family members, estimated as closely as possible. (Reassure of confidentiality. Supplement with monthly rates to help them figure.)

$$
\begin{aligned}
& 0-\$ 1,499 \\
& \$ 1,500-\$ 2,999 \\
& \$ 3,000-\$ 4,499 \\
& \$ 4,500-\$ 5,999 \\
& \$ 6,000-\$ 7,499 \\
& \$ 7,500-\$ 8,999 \\
& \$ 9,000-\$ 10,499 \\
& \$ 10,500-\$ 11,999 \\
& \$ 12,000-\$ 13,499 \\
& \$ 13,500-\$ 14,999 \\
& \$ 15,000-\$ 16,499
\end{aligned}
$$

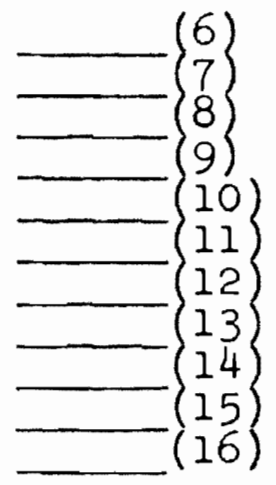

II. Housing:

Do you rent?

Are you buying?

Do you own your home? (paid for)

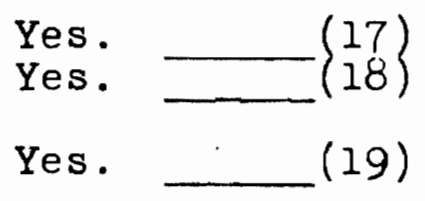

Note:

\section{Apartment}

Duplex

Single-family dwelling

Age of house:

How old is this house? (Estimate)

$$
\begin{aligned}
& 0-9 \\
& 10-19 \\
& 20-29 \\
& 30-39 \\
& 40-49 \\
& 50+
\end{aligned}
$$

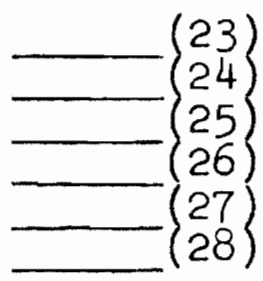


IV. Heating

What kind of fuel do you use for heating?

$$
\begin{aligned}
& \text { Gas } \\
& \text { Oil } \\
& \text { Electricity }
\end{aligned}
$$

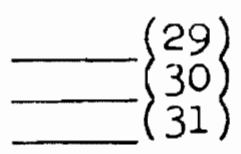

V. Ef'fects of increased fuel costs on budget (attitudes): How has the increased cost of fuel affected your household budget?

None

$$
\begin{aligned}
& \text { Strain, but no sacrifice } \\
& \text { of essentials } \\
& \text { Must Juggle bilis or pay } \\
& \text { late } \\
& \text { Without heat on occasion } \\
& \text { other problems (note) }
\end{aligned}
$$

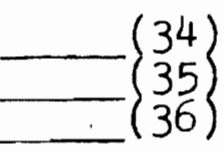

VI. Adaptation

What have you done to cut down or save fuel?

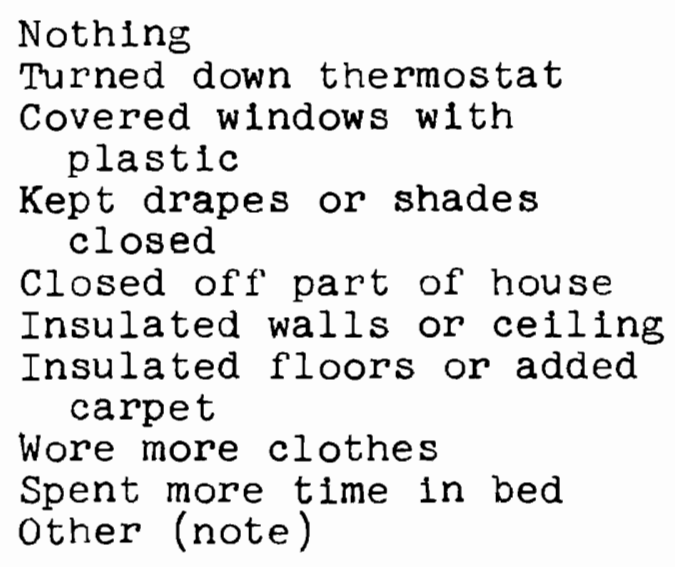

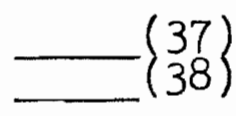
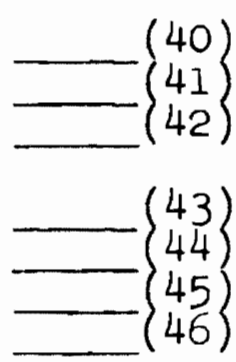

Close:

We hope to put together some information that might be helpful to you and others with similar problems. We appreclate your cooperation. Thank you. 